\title{
BIOMECHANICAL EVALUATION OF VERTEBROPLASTY AND KYPHOPLASTY BY UNIAXIAL COMPRESSIVE TEST
}

Márta Kurutz ${ }^{1}$, Gábor Jakab² ${ }^{2}$ Péter Varga ${ }^{3}$, Péter Pál Varga ${ }^{2}$

${ }^{1}$ Budapest University of Technology and Economics

${ }^{2}$ National Center for Spinal Disorders, Budapest

3Julius Wolff Institute and Berlin-Brandenburg School for Regenerative Therapies, Charitè -

Universitätsmedizin

keurutym@eik.bme.bu

\begin{abstract}
In vertebroplasty, by injecting cement into the fractured osteoporotic vertebra, the cement can leak into the surrounding soft tissues. To avoid this injurious side-effect, in kyphoplasty a suitable place is previously prepared for the cement, by an inflated and removed balloon. In this study the biomechanical evaluation of vertebroplasty and kyphoplasty is presented by comparing the strength, stiffness and deformability of post-operated vertebrae by using uniaxial compressive mechanical test. As for conclusion, mechanical properties following vertebroplasty are more sensitive to initial bone density than after kyphoplasty, however, both techniques give practically the same failure load, vertebroplasty yields larger stiffness and smaller compressive deformability.
\end{abstract}

Keywords: vertebroplasty, kyphoplasty, mechanical compressive test, failure load, failure displacement, compressive stiffness

\section{Introduction}

Percutaneous vertebroplasty and kyphoplasty are well-established minimally invasive treatments for compression fractures of osteoporotic vertebral bodies. ${ }^{1-7}$ In vertebroplasty, bone cement is injected through a needle into the fractured osteoporotic cancellous bone of the vertebra. In this case, the cement can leak into the soft tissues and veins and neural foramen surrounding the vertebra, causing further complications. To avoid this side-effect, in kyphoplasty, a balloon is first inserted and inflated to expand the compressed vertebra to its height more or less, and to prepare the place for the cement to be injected. After removing the balloon, the cement is injected into its prepared place. The benefit of kyphoplasty besides preventing cement leakage is that the vertebra partly recovers its height before the bone hardens. Without these treatments, the fractures will eventually heal, but in their collapsed position.

In this study the biomechanical evaluation of vertebroplasty and kyphoplasty is presented by comparing the strength, stiffness and deformability of post-operated vertebrae by using uniaxial compressive mechanical test.

\section{Methods}

The specimens were prepared in the National Center for Spinal Disorders in Budapest, and the compression tests were executed in the laboratory of the Biomechanical Research Centre of the Budapest University of Technology and Economics. 
At present, for the specimens 44 lumbar vertebrae were extracted from 13 human female cadaveric lumbar spines (spine/level/gender/age): A/L1-L4/F/60; B/L1-L3/F/60; C/L1-L3//-; D/T12-L5F/51; E/L1-L4/F/57; F/L1-L4/F/95; G/L1-L4/-/-; H/L1-L4/F/80; I/L1L4/F/70; J/L1-L5F/60; K/L1-L5/F/88, L/L1-L3/F/, M/L1-L2/F. The 44 vertebrae were divided into 3 groups: 7 native vertebrae (NV), 16 vertebrae for vertebroplasty (VP) and 21 vertebrae for kyphoplasty (KP). In the VP group a total volume of $6 \mathrm{ml}$ of PMMA cement was injected, in 3-3 ml bipedicular way. Similarly, in the KP group, 3-3 ml PMMA cement was injected into the place of inflated and removed two balloons, yielding a total value of $6 \mathrm{ml}$, as well. Thus, the same amount of cement was injected into all VP and KP augmented vertebrae.

The VP and KP groups were further divided into two groups: 8 vertebra from VP group for thick embedding (VP1) group and 8 for thin embedding (VP2) group; 10 vertebra from KP group for thick embedding (KP1) group and 11 for thin embedding (KP2) group. The specimens of thick and thin embedding groups were embedded parallel to about 8,6 and 3,6 mm polymethylmethacrylate PMMA discs, respectively, around the inferior and superior endplates of vertebrae. The native vertebrae remained without embedding.

Both the pre- and post-operated specimens were scanned individually with a high-resolution quantitative computed tomography (QCT) system (Hitachi Presto, Hitachi Medical Corporation, Tokyo, Japan) to provide 3D density maps of the vertebral bodies. The samples were scanned in native state submerged in a water filled box. The PMMA embedding of specimens were transparent in CT to distinguish correctly the bone and embedding, so the bordering planes of embeddings were marked by glass pearls. Vertebral heights, central cross sectional areas, CT grey values were measured from QCT images. The CT scan was performed for each specimen after the mechanical test as well. The specimens were stored at $-200 \mathrm{C}$ and were thawed at room temperature 4-6 hours before testing.

Table $1 a$ and $1 b$ illustrate the data of pre-operated specimens for the thick and thin embedded groups, respectively.

Thick embedded groups (VP1 and KP1)

\begin{tabular}{|c|c|c|c|c|c|c|c|c|c|c|c|c|c|}
\hline Specimen & Sample & $\begin{array}{c}\text { Age } \\
(\mathrm{yrs})\end{array}$ & Sex & $\begin{array}{c}\text { Height } \\
(\mathrm{mm})\end{array}$ & $\begin{array}{c}\text { Area } \\
\left(\mathrm{mm}^{2}\right)\end{array}$ & $\begin{array}{c}\text { CT- } \\
\text { grey }\end{array}$ & Specimen & Sample & $\begin{array}{c}\text { Age } \\
(\mathrm{yrs})\end{array}$ & Sex & $\begin{array}{c}\text { Height } \\
(\mathrm{mm})\end{array}$ & $\begin{array}{c}\text { Area } \\
\left(\mathrm{mm}^{2}\right)\end{array}$ & $\begin{array}{c}\text { CT- } \\
\text { grey }\end{array}$ \\
\hline VP1 group & & & & & & & KP1 group & & & & & & \\
\hline VP1/1 & A/L1 & 60 & F & 26,89 & 1199 & 201 & KP1/1 & A/L2 & 60 & F & 26,81 & 1349 & 192 \\
\hline VP1/2 & A/L3 & 60 & F & 27,10 & 1366 & 193 & KP1/2 & A/L4 & 60 & F & 26,96 & 1445 & 161 \\
\hline VP1/3 & $\mathbf{B / L 1}$ & 60 & F & 30,25 & 1437 & - & KP1/3 & B/L2 & 60 & F & 29,30 & 1426 & - \\
\hline VP1/4 & $\mathbf{B / L 3 ~}$ & 60 & F & 26,84 & 1566 & - & KP1/4 & C/L1 & - & - & 30,55 & 1431 & 134 \\
\hline VP1/5 & C/L2 & - & - & 31,33 & 1562 & 115 & KP1/5 & C/L3 & - & - & 31,65 & 1661 & 136 \\
\hline VP1/6 & D/L1 & 51 & F & 27,79 & 1112 & 174 & KP1/6 & D/T12 & 51 & F & 26,99 & 1244 & 164 \\
\hline VP1/7 & D/L3 & 51 & F & 27,58 & 1341 & 114 & KP1/7 & D/L2 & 51 & F & 27,42 & 1211 & 126 \\
\hline VP1/8 & $\mathbf{D / L 5 ~}$ & 51 & F & 26,18 & 1379 & 162 & KP1/8 & D/L4 & 51 & F & 27,65 & 1355 & 141 \\
\hline mean & & $\mathbf{5 6}$ & & $\mathbf{2 8 , 0 0}$ & $\mathbf{1 3 7 0}$ & $\mathbf{1 3 1}$ & mean & & $\mathbf{5 6}$ & & $\mathbf{2 8 , 4 2}$ & $\mathbf{1 3 9 0}$ & $\mathbf{1 5 1}$ \\
\hline SD & & $\mathbf{4 , 8}$ & & $\mathbf{1 , 8 2}$ & $\mathbf{1 5 9}$ & $\mathbf{6 3}$ & SD & & $\mathbf{4 , 9}$ & & $\mathbf{1 , 8 6}$ & $\mathbf{1 3 9}$ & $\mathbf{2 3}$ \\
\hline
\end{tabular}

Table 1a. Data of pre-operated specimens for the thick embedded groups 
Thin embedded groups (VP2 and KP2)

\begin{tabular}{|c|c|c|c|c|c|c|c|c|c|c|c|c|c|}
\hline Specimen & Sample & $\begin{array}{l}\text { Age } \\
\text { (yrs) }\end{array}$ & Sex & $\begin{array}{c}\text { Height } \\
(\mathrm{mm})\end{array}$ & $\begin{array}{c}\text { Area } \\
\left(\mathrm{mm}^{2}\right)\end{array}$ & $\begin{array}{l}\text { CT- } \\
\text { grey }\end{array}$ & Specimen & Sample & $\begin{array}{l}\text { Age } \\
\text { (yrs) }\end{array}$ & Sex & $\begin{array}{c}\text { Height } \\
(\mathrm{mm})\end{array}$ & $\begin{array}{c}\text { Area } \\
\left(\mathrm{mm}^{2}\right)\end{array}$ & $\begin{array}{l}\text { CT- } \\
\text { grey }\end{array}$ \\
\hline VP2 group & & & & & & & KP2 group & & & & & & \\
\hline VP2/1 & E/L1 & 57 & $\bar{F}$ & 26,75 & 985 & 143 & KP2/1 & E/L2 & 57 & F & 28,41 & 977 & 152 \\
\hline VP2/2 & $\mathrm{E} / \mathrm{L3}$ & 57 & $\mathrm{~F}$ & 27,19 & 1113 & 171 & KP2/2 & E/L4 & 57 & $\mathrm{~F}$ & 27,31 & 1078 & 121 \\
\hline VP2/3 & G/L2 & - & $\mathrm{F}$ & 27,81 & 1244 & 99 & KP2/3 & G/L3 & - & F & 28,57 & 1390 & 67 \\
\hline VP2/4 & I/L1 & 70 & $\mathrm{~F}$ & 25,63 & 832 & 183 & KP2/4 & I/L2 & 70 & F & 27,59 & 959 & 179 \\
\hline VP2/5 & I/L3 & 70 & $\mathrm{~F}$ & 26,46 & 1000 & 178 & KP2/5 & I/L4 & 70 & F & 27,58 & 1235 & 86 \\
\hline VP2/6 & H/L2 & 80 & $\mathrm{~F}$ & 25,01 & 1200 & 243 & KP2/6 & K/L1 & 88 & F & 21,94 & 919 & 138 \\
\hline VP2/7 & J/L3 & 68 & $\mathrm{~F}$ & 28,99 & 1152 & 158 & KP2/7 & H/L1 & 80 & F & 25,14 & 1239 & 147 \\
\hline VP2/8 & J/L5 & 68 & $\mathrm{~F}$ & 29,09 & 1277 & 191 & KP2/8 & J/L1 & 68 & $F$ & 25,85 & 973 & 166 \\
\hline VP2/9 & F/L2 & 95 & $\mathrm{~F}$ & 25,55 & 921 & 88 & KP2/9 & J/L4 & 68 & $\mathrm{~F}$ & 30,39 & 1319 & 146 \\
\hline \multirow[t]{2}{*}{ VP2/10 } & F/L4 & 95 & $\mathrm{~F}$ & 26,17 & 1045 & 43 & KP2/10 & F/L2 & 95 & $\mathrm{~F}$ & 24,68 & 787 & 67 \\
\hline & & & & & & & KP2/11 & F/L4 & 95 & $F$ & 25,43 & 951 & 72 \\
\hline mean & & 73 & & 26,87 & 1077 & 150 & mean & & 75 & & 26,63 & 1075 & 122 \\
\hline SD & & 14 & & 1,41 & 145 & 58 & SD & & 14 & & 2,31 & 192 & 42 \\
\hline
\end{tabular}

Table 1b. Data of pre-operated specimens for the thin embedded groups

The compressive mechanical test was executed by using a servohydraulic testing machine (Instron 8870 series). Axial compressive displacement load was applied at a rate of $5 \mathrm{~mm} / \mathrm{min}$ speed, to the limit of $20 \%$ decrease of the compressive force or $20 \%$ of compressive strain of the specimen. Axial compressive force and displacement were measured and the relating forcedisplacement curve was plotted. Failure load $(\mathrm{N})$, failure displacement $(\mathrm{mm})$ and structural stiffness $(\mathrm{N} / \mathrm{mm})$ were extracted from the load-displacement curves. Failure load was the maximum load before the gradient of the curve changed from positive to negative, whereas stiffness was the slope of the linear portion of the load-displacement curve before failure occurred. Dividing the failure displacements by the original heights of the vertebrae, failure strains were also calculated. Based on the elastic stiffness, Young's moduli of augmented vertebrae were obtained as well.

\section{Results}

Table $2 a, 2 b$ and $2 c$ illustrate the values of failure load, elastic stiffness, Young's modulus, failure displacements (height losses) and failure strains extracted and calculated from the loaddisplacement diagrams obtained from the mechanical compressive tests, for the native vertebrae and for the thick and thin embedded groups, respectively. Mean failure load, stiffness and failure height loss of groups with thick and thin embeddings are seen in Figure 1.

Compressive failure load was practically not affected by the augmentation types, it was not significantly different for VP and KP groups in thick $(\mathrm{P}=0.40)$ and thin $(\mathrm{P}=0.31)$ embedded groups; it was only about $8 \%$ smaller in thin embedded groups for $\mathrm{KP}$ vertebrae, compared to the VP ones (Figure 1a). Compared to the native vertebrae without embedding, the failure load was significantly, 76-78\% ( $\mathrm{P}=0.002)$ higher in thick, but only $21-11 \%(\mathrm{P}=0.088)$ higher in thin embedded groups, for VP and KP vertebrae, respectively. 


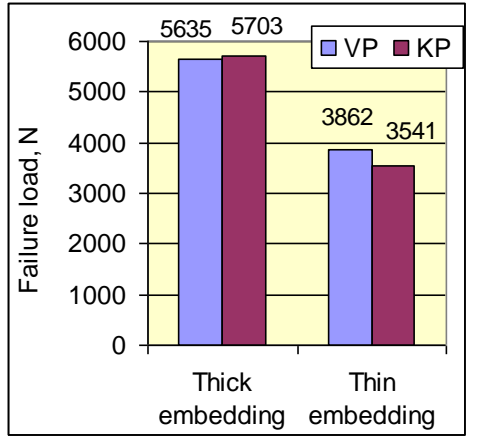

a)

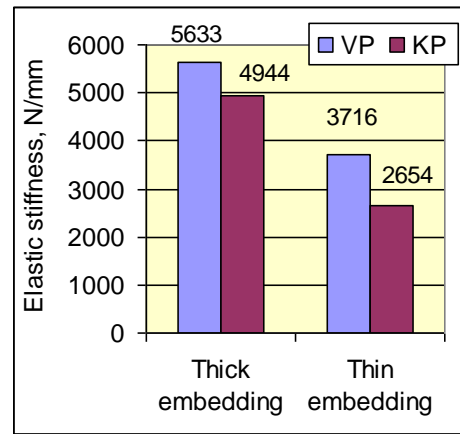

b)

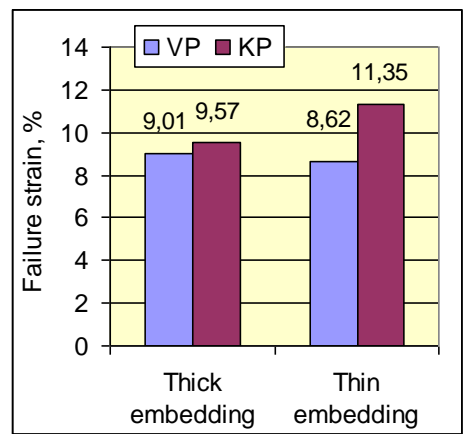

c)

Figure 1: Mean failure load (a), stiffness (b) and failure height loss (c) of VP and KP groups with thick (VP1, KP1) and thin (VP2, KP2) embeddings

Native vertebrae (NV group)

\begin{tabular}{|c|c|c|c|c|c|c|c|c|c|}
\hline $\begin{array}{l}\text { Speci } \\
\text { men }\end{array}$ & Sample & Sex & $\begin{array}{c}\text { Height } \\
\text { (mm) }\end{array}$ & $\begin{array}{l}\text { Area } \\
\left(\mathrm{mm}^{2}\right)\end{array}$ & $\begin{array}{c}\text { Failure } \\
\text { load } \\
(\mathrm{N})\end{array}$ & $\begin{array}{l}\text { Stiffness } \\
(\mathrm{N} / \mathrm{mm})\end{array}$ & $\begin{array}{c}\text { Young } \\
\text { mod } \\
(\mathrm{MPa})\end{array}$ & $\begin{array}{c}\text { Failure } \\
\text { short. } \\
\text { (mm) }\end{array}$ & $\begin{array}{c}\text { Failure } \\
\text { strain } \\
\%\end{array}$ \\
\hline \multicolumn{10}{|c|}{ NV group } \\
\hline $\mathrm{NV} / 1$ & L/L1 & $\mathrm{F}$ & 27,5 & 908 & 2210 & 750 & 23 & 5,00 & 18,18 \\
\hline $\mathrm{NV} / 2$ & L/L3 & $\mathrm{F}$ & 30,5 & 1320 & 2548 & 779 & 18 & 4,69 & 15,38 \\
\hline $\mathrm{NV} / 3$ & G/L4 & - & 28,0 & 1134 & 2986 & 656 & 16 & 5,66 & 20,21 \\
\hline $\mathrm{NV} / 4$ & G/L1 & - & 20,0 & 962 & 3140 & 1056 & 22 & 6,04 & 30,20 \\
\hline $\mathrm{NV} / 5$ & M/L1 & $\mathrm{F}$ & 24,0 & 855 & 3483 & 915 & 26 & 7,35 & 30,63 \\
\hline NV /6 & M/L2 & $\mathrm{F}$ & 26,0 & 908 & 4711 & 1031 & 30 & 7,94 & 30,54 \\
\hline NV /7 & L/L2 & $\mathrm{F}$ & 30,0 & 1015 & 3293 & 759 & 22 & 7,72 & 25,73 \\
\hline mean & & & 26,57 & 1370 & 3196 & 849 & 22 & 6,34 & 24,41 \\
\hline SD & & & 3,66 & 163 & 799 & 153 & 4 & 1,33 & 6,45 \\
\hline
\end{tabular}

Table 2a. Mechanical parameters of native vertebrae

Thick embedded groups (VP1 and KP1)

\begin{tabular}{|c|c|c|c|c|c|c|c|c|c|c|c|}
\hline $\begin{array}{c}\text { Speci } \\
\text { men }\end{array}$ & $\begin{array}{c}\text { Failure } \\
\text { load } \\
(\mathrm{N})\end{array}$ & $\begin{array}{c}\text { Stiffness } \\
(\mathrm{N} / \mathrm{mm})\end{array}$ & $\begin{array}{c}\text { Young } \\
\text { mod } \\
(\mathrm{MPa})\end{array}$ & $\begin{array}{c}\text { Failure } \\
\text { short. } \\
(\mathrm{mm})\end{array}$ & $\begin{array}{c}\text { Failure } \\
\text { strain } \\
\%\end{array}$ & $\begin{array}{c}\text { Speci } \\
\text { men }\end{array}$ & $\begin{array}{c}\text { Failure } \\
\text { load } \\
(\mathrm{N})\end{array}$ & $\begin{array}{c}\text { Stiffness } \\
(\mathrm{N} / \mathrm{mm})\end{array}$ & $\begin{array}{c}\text { Young } \\
\text { mod } \\
(\mathrm{MPa})\end{array}$ & $\begin{array}{c}\text { Failure } \\
\text { short. } \\
(\mathrm{mm})\end{array}$ & $\begin{array}{c}\text { Failure } \\
\text { strain } \\
\%\end{array}$ \\
\hline $\begin{array}{c}\text { VP1 } \\
\text { group }\end{array}$ & & & & & & $\begin{array}{c}\text { KP1 } \\
\text { group }\end{array}$ & & & & & \\
\hline VP1/1 & 5300 & 6818 & 153 & 1,61 & 5,99 & $\mathbf{K P 1 / 1}$ & 5449 & 4854 & 96 & 2,08 & 7,76 \\
\hline VP1/2 & 5688 & 7692 & 153 & 1,59 & 5,87 & $\mathbf{K P 1 / 2}$ & 5022 & 4000 & 75 & 2,62 & 9,72 \\
\hline VP1/3 & 4263 & 6849 & 144 & 1,43 & 4,73 & KP1/3 & 4546 & 5556 & 114 & 2,09 & 7,13 \\
\hline VP1/4 & 7846 & 8046 & 138 & 2,97 & 11,07 & KP1/4 & 6403 & 4630 & 99 & 4,50 & 14,73 \\
\hline VP1/5 & 5887 & 5000 & 100 & 3,77 & 12,03 & KP1/5 & 6786 & 6329 & 121 & 2,74 & 8,66 \\
\hline VP1/6 & 4132 & 3419 & 85 & 1,90 & 6,84 & $\mathbf{K P 1 / 6}$ & 4197 & 4040 & 88 & 2,20 & 8,15 \\
\hline VP1/7 & 6393 & 3593 & 74 & 3,75 & 13,60 & KP1/7 & 6951 & 5185 & 117 & 2,91 & 10,61 \\
\hline VP1/8 & 5573 & 3650 & 69 & 3,13 & 11,96 & KP1/8 & 6270 & 4959 & 101 & 2,70 & 9,76 \\
\hline mean & $\mathbf{5 6 3 5}$ & $\mathbf{5 6 3 3}$ & $\mathbf{1 1 5}$ & $\mathbf{2 , 5 2}$ & $\mathbf{9 , 0 1}$ & mean & $\mathbf{5 7 0 3}$ & $\mathbf{4 9 4 4}$ & $\mathbf{1 0 1}$ & $\mathbf{2 , 7 3}$ & $\mathbf{9 , 5 7}$ \\
\hline SD & $\mathbf{1 1 8 2}$ & $\mathbf{1 9 4 0}$ & $\mathbf{3 6}$ & $\mathbf{0 , 9 9}$ & $\mathbf{3 , 4 9}$ & $\mathbf{S D}$ & $\mathbf{1 0 4 7}$ & $\mathbf{7 7 1}$ & $\mathbf{1 6}$ & $\mathbf{0 , 7 8}$ & $\mathbf{2 , 3 9}$ \\
\hline
\end{tabular}

Table $2 b$. Mechanical parameters of specimens in the thick embedded groups 
Thin embedded groups (VP2 and KP2)

\begin{tabular}{|c|c|c|c|c|c|c|c|c|c|c|c|}
\hline $\begin{array}{c}\text { Speci } \\
\text { men }\end{array}$ & $\begin{array}{c}\text { Failure } \\
\text { load } \\
(\mathrm{N})\end{array}$ & $\begin{array}{c}\text { Stiffness } \\
(\mathrm{N} / \mathrm{mm})\end{array}$ & $\begin{array}{c}\text { Young } \\
\text { mod } \\
(\mathrm{MPa})\end{array}$ & $\begin{array}{c}\text { Failure } \\
\text { short. } \\
(\mathrm{mm})\end{array}$ & $\begin{array}{c}\text { Failure } \\
\text { strain } \\
\%\end{array}$ & $\begin{array}{c}\text { Speci } \\
\text { men }\end{array}$ & $\begin{array}{c}\text { Failure } \\
\text { load } \\
(\mathrm{N})\end{array}$ & $\begin{array}{c}\text { Stiffness } \\
(\mathrm{N} / \mathrm{mm})\end{array}$ & $\begin{array}{c}\text { Young } \\
\text { mod } \\
(\mathrm{MPa})\end{array}$ & $\begin{array}{c}\text { Failure } \\
\text { short } \\
(\mathrm{mm})\end{array}$ & $\begin{array}{c}\text { Failure } \\
\text { strain } \\
\%\end{array}$ \\
\hline $\begin{array}{c}\text { VP2 } \\
\text { group }\end{array}$ & & & & & & $\begin{array}{c}\text { KP2 } \\
\text { group }\end{array}$ & & & & & \\
\hline VP2/1 & 2400 & 2609 & 71 & 2,45 & 9,16 & $\mathbf{K P 2 / 1}$ & 3480 & 1676 & 49 & 4,82 & 16,97 \\
\hline VP2/2 & 4595 & 4255 & 104 & 2,44 & 8,97 & $\mathbf{K P 2 / 2}$ & 3380 & 3614 & 92 & 2,08 & 7,62 \\
\hline VP2/3 & 3884 & 2752 & 62 & 2,78 & 10,00 & $\mathbf{K P 2 / 3}$ & 4033 & 2985 & 61 & 3,64 & 12,74 \\
\hline VP2/4 & 3537 & 3846 & 118 & 1,84 & 7,18 & $\mathbf{K P 2 / 4}$ & 3583 & 2419 & 70 & 3,49 & 12,65 \\
\hline VP2/5 & 4000 & 4255 & 113 & 2,24 & 8,47 & $\mathbf{K P 2 / 5}$ & 3767 & 2222 & 50 & 3,51 & 12,73 \\
\hline VP2/6 & 6944 & 4778 & 100 & 3,53 & 14,11 & $\mathbf{K P 2 / 6}$ & 3261 & 2222 & 53 & 2,88 & 13,13 \\
\hline VP2/7 & 3889 & 3571 & 90 & 2,16 & 7,45 & $\mathbf{K P 2 / 7}$ & 6593 & 4380 & 89 & 3,19 & 12,69 \\
\hline VP2/8 & 4444 & 6154 & 140 & 1,49 & 5,12 & $\mathbf{K P 2 / 8}$ & 2832 & 2569 & 68 & 2,69 & 10,41 \\
\hline VP2/9 & 2009 & 2632 & 73 & 1,47 & 5,75 & $\mathbf{K P 2 / 9}$ & 2738 & 2391 & 55 & 2,26 & 7,44 \\
\hline VP2/10 & 2913 & 2308 & 58 & 2,61 & 9,97 & $\mathbf{K P 2 / 1 0}$ & 2194 & 2410 & 76 & 2,00 & 8,10 \\
\hline & & & & & & $\mathbf{K P 2 / 1 1}$ & 3091 & 2308 & 62 & 2,64 & 10,38 \\
\hline mean & $\mathbf{3 8 6 2}$ & $\mathbf{3 7 1 6}$ & $\mathbf{9 3}$ & $\mathbf{2 , 3 0}$ & $\mathbf{8 , 6 2}$ & $\mathbf{m e a n}$ & $\mathbf{3 5 4 1}$ & $\mathbf{2 6 5 4}$ & $\mathbf{6 6}$ & $\mathbf{3 , 0 2}$ & $\mathbf{1 1 , 3 5}$ \\
\hline SD & $\mathbf{1 3 7 3}$ & $\mathbf{1 2 0 2}$ & $\mathbf{2 7}$ & $\mathbf{0 , 6 2}$ & $\mathbf{2 , 5 4}$ & $\mathbf{S D}$ & $\mathbf{1 1 3 5}$ & $\mathbf{7 5 2}$ & $\mathbf{1 5}$ & $\mathbf{0 , 8 3}$ & $\mathbf{2 , 8 9}$ \\
\hline
\end{tabular}

Table 2c. Mechanical parameters of specimens in the thin embedded groups

Compressive stiffness for KP treatment was $12 \%$ smaller in thick $(\mathrm{P}=0.18)$ and $29 \%$ smaller in thin $(\mathrm{P}=0.02)$ embedded groups, compared to the VP one (Figure 1b). Compared to the native vertebrae where the stiffness was very low, in the thick embedded group it was 5,6-4,8 times higher $(\mathrm{P}<0.00001)$ and in the thin embedded group 2,1-3,4 times higher $(\mathrm{P}<0.0001)$, for VP and $\mathrm{KP}$ vertebrae, respectively. Similar difference and ratio was observed in Young's moduli of augmented vertebrae compared to the native ones.

Compressive vertebral height loss related to the original height, namely, the compressive strain was $6 \%$ larger in the thick $(\mathrm{P}=0.35)$ and $32 \%$ larger in thin $(\mathrm{P}=0.018)$ embedded groups for $\mathrm{KP}$ than for VP augmentation (Figure 1c). Related to the native vertebrae the strain was significantly smaller, by $63-61 \%$ in the thick and by $65-58 \%$ in the thin embedded groups for VP $(\mathrm{P}<0.00001)$ and $\mathrm{KP}(\mathrm{P}<0.001)$ vertebrae, respectively.

However, the embedding thickness significantly affected most of the mechanical results. The failure load of the thin embedded groups was $32 \%$ smaller for VP ( $\mathrm{P}=0.018)$ and $38 \%$ smaller for $\mathrm{KP}(\mathrm{P}=0.0016)$ vertebrae compared to the thick embedded groups (Figure 1a). Elastic stiffness of the thin embedded groups was $34 \%$ smaller for $\mathrm{VP}(\mathrm{P}=0.031)$ and $46 \%$ smaller for $\mathrm{KP}$ $(\mathrm{P}=0.0006))$ vertebrae compared to the thick ${ }^{21}$ embedded groups (Figure 1b). However, failure strain of the thin embedded groups was only $4 \%$ smaller for VP $(\mathrm{P}=0.45)$ but $19 \%$ larger for KP vertebrae $(\mathrm{P}=0.021)$, compared to the thick embedded groups (Figure 1c).

Correlation between the failure load and the bone quality of thick and thin embedded VP and KP vertebrae can be seen in Figure 2. Surprisingly, while the failure load of VP2 vertebrae showed a good positive correlation with CT grey $(\mathrm{R}=0,75), \mathrm{VP} 1$ in thin embedded group had a small negative correlation $(\mathrm{R}=-0,32)$. KP vertebrae had no correlation at all, neither in thick and nor in thin embedding. 


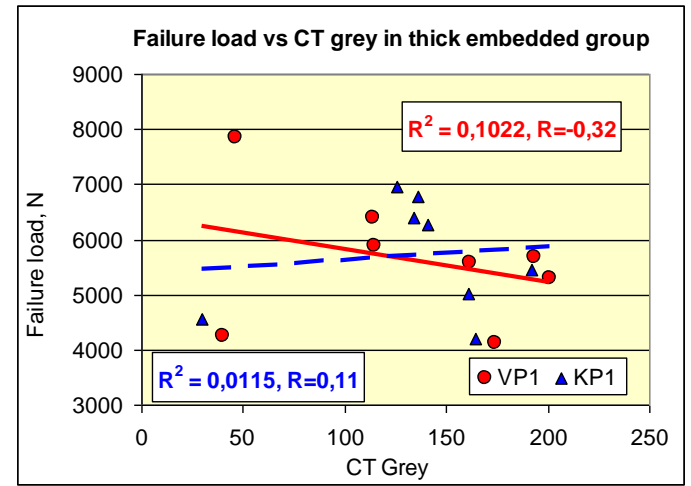

a)

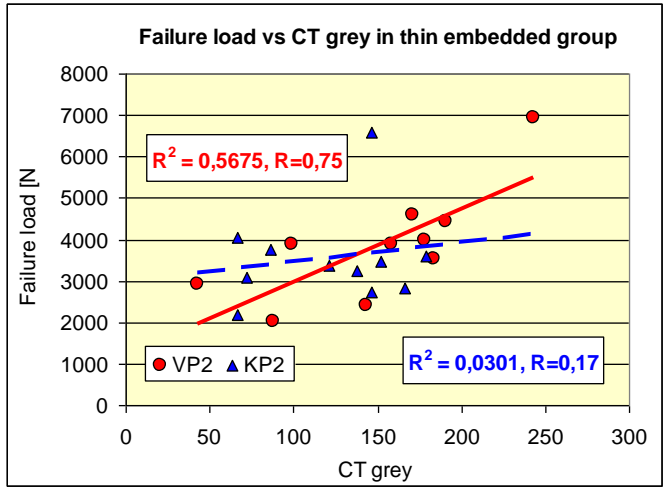

b)

Figure 2: Failure load versus CT-grey of VP and KP groups in a) thick and b) thin embeddings

Correlation between the elastic stiffness and the bone quality of thick and thin embedded VP and KP vertebrae can be seen in Figure 3. Surprisingly, while the stiffness of VP2 vertebrae showed a good positive correlation with CT grey $(\mathrm{R}=0,80)$, VP1 in thin embedded group had practically no correlation $(\mathrm{R}=-0,25)$, similar to the KP vertebrae both in thick and thin embedded groups.

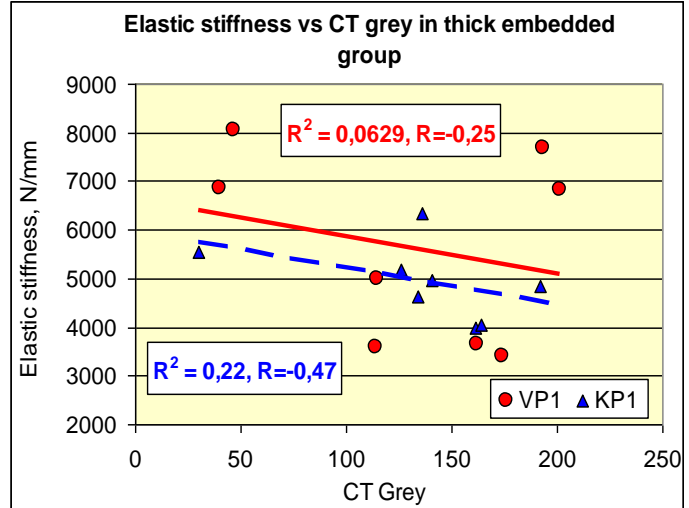

a)

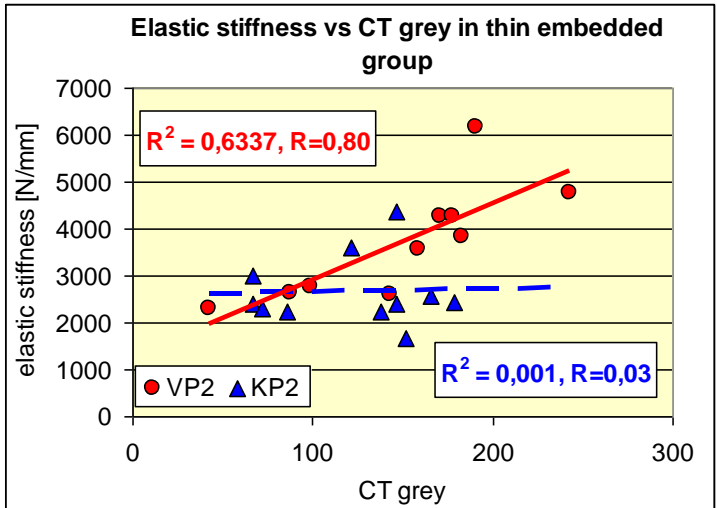

b)

Figure 3: Elastic stiffness versus CT-grey of VP and KP groups in a) thick and b) thin embeddings

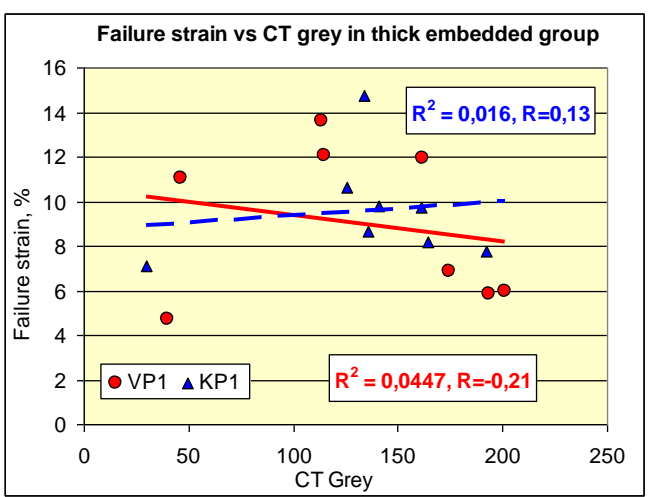

a)

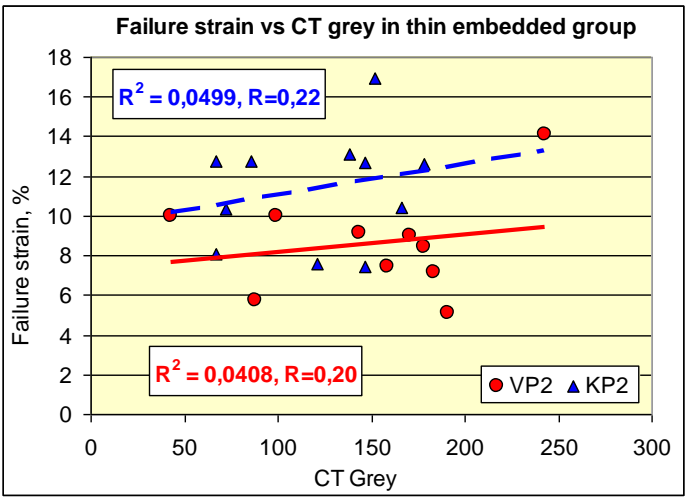

b)

Figure 4: Failure shortening versus CT-grey of VP and KP groups in a) thick and b) thin embeddings 
Correlation between the failure strain and the bone quality of thick and thin embedded VP and KP vertebrae can be seen in Figure 4. Practically, both VP and KP vertebrae had no correlation, neither in thick and nor in thin embedded groups.

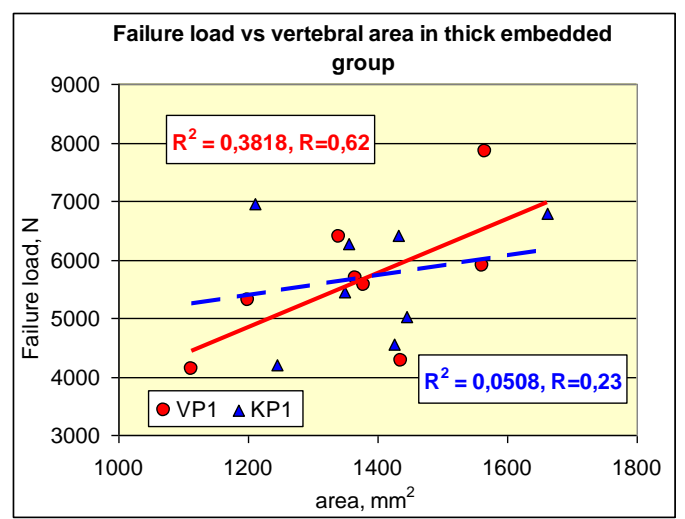

a)

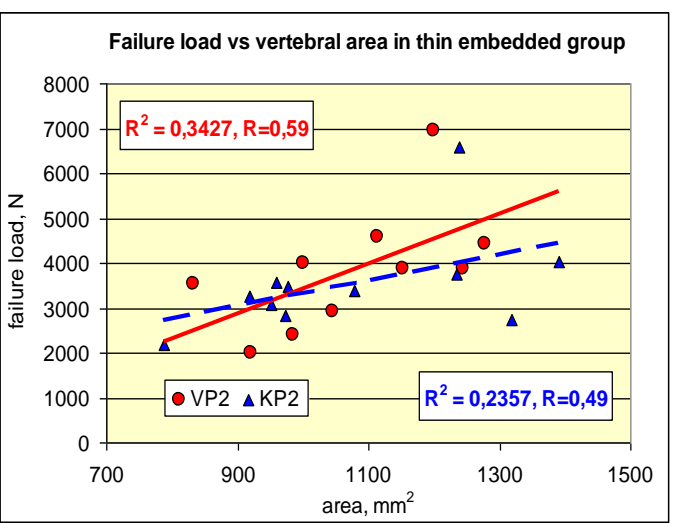

b)

Figure 5: Failure load versus vertebral area of VP and KP groups in a) thick and b) thin embeddings

Correlation between the failure load and the cross sectional area of vertebrae of thick and thin embedded VP and KP vertebrae can be seen in Figure 5. While the VP vertebrae show a modest positive correlation in both the thick and thin embedded groups $(R=0,69$ and $R=0,59$, respectively), KP vertebrae had a little positive correlation in thin embedded groups $(\mathrm{R}=0,49)$.

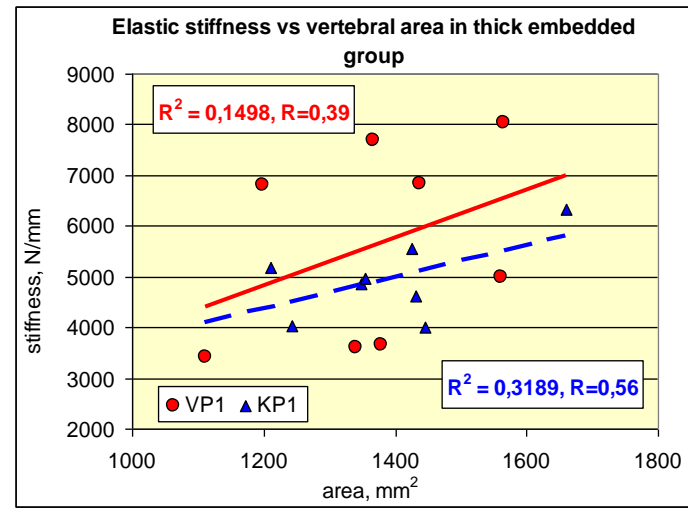

a)

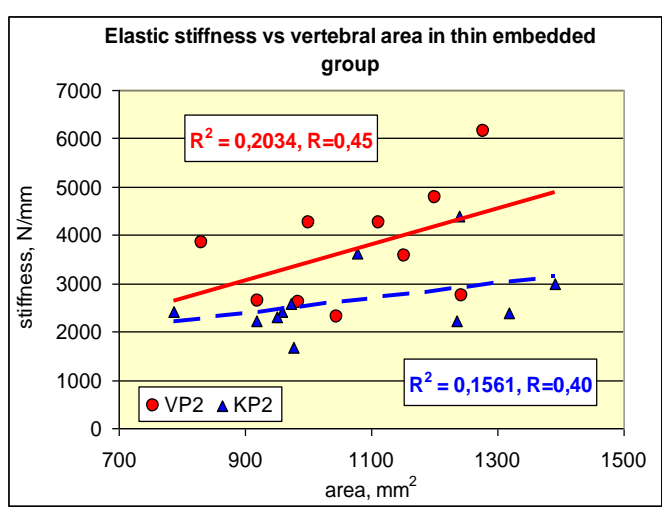

b)

Figure 6: Elastic stiffness versus vertebral area of VP and KP groups in a) thick and b) thin embeddings

Correlation between the elastic stiffness and the cross sectional area of vertebrae of thick and thin embedded VP and KP vertebrae can be seen in Figure 6. Both VP and KP vertebrae show a modest positive correlation in both the thick and thin embedded groups.

Correlation between the failure strains and the cross sectional area of vertebrae of thick and thin embedded VP and KP vertebrae can be seen in Figure 7. While the VP vertebrae show a little positive correlation in the thick embedded groups $(\mathrm{R}=0.43)$, KP vertebrae had practically no correlation, neither in thick and nor in thin embedded groups. 


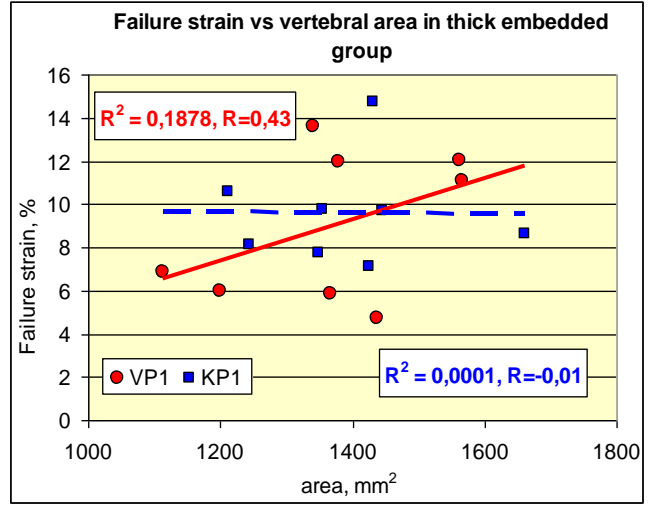

a)

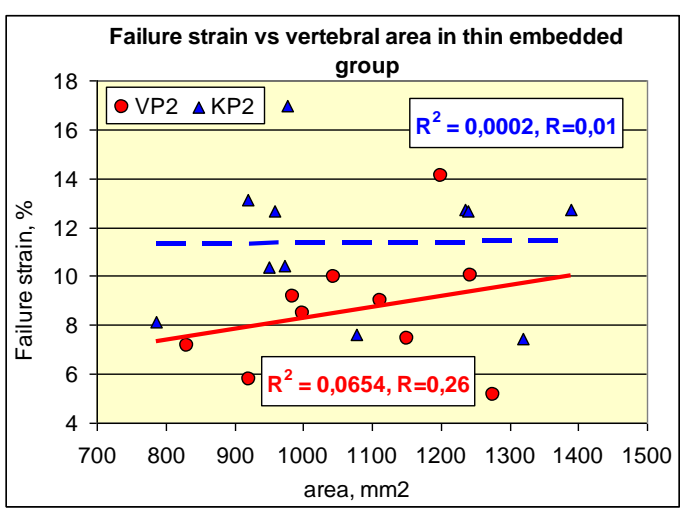

b)

Figure 7: Failure strain versus vertebral area of VP and KP groups in a) thick and b) thin embeddings

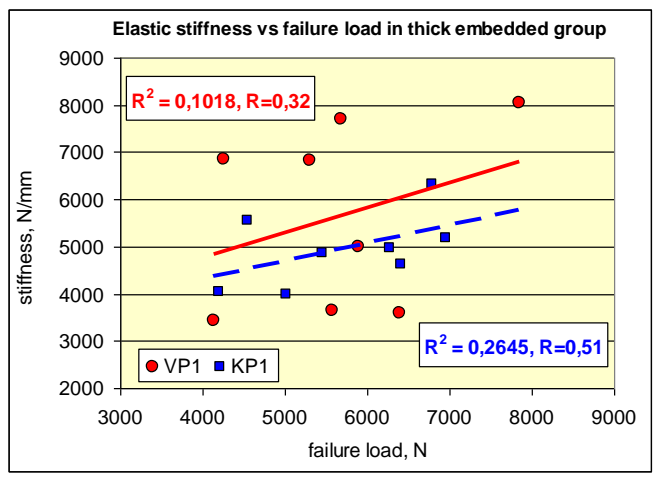

a)

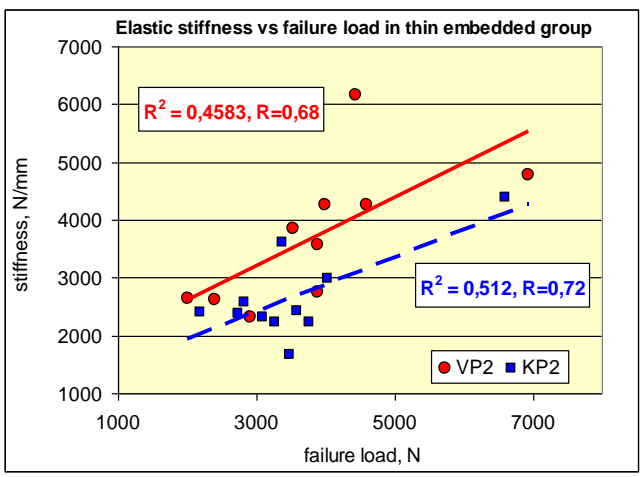

b)

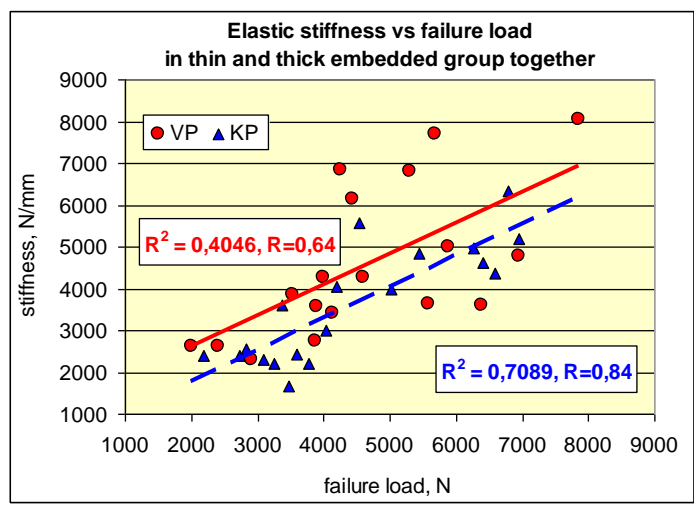

c)

Figure 8: Elastic stiffness vs failure load in a) thick, b) thin and c) thick and thin embedded groups

Correlation between the elastic stiffness and failure load of vertebrae of thick and thin embedded $\mathrm{VP}$ and KP vertebrae can be seen in Figures $8 a$ and $8 b$, for the unified tick and thin embedded groups in Figure $8 c$. In the thin embedded group both VP2 $(\mathrm{R}=0.68)$ and $\mathrm{KP} 2(\mathrm{R}=0.72$, ) vertebrae had higher correlation between stiffness and failure load than in the thick embedded group VP1 $(\mathrm{R}=0.32)$ and $\mathrm{KP1}(\mathrm{R}=0.51)$ groups. KP vertebrae had higher correlation in both the thick and thin or in the unified thick and thin embedded group $(R=0.84)$ than VP vertebrae $(R=0.64)$. 
The effect of embedding thickness on the failure load, elastic stiffness and failure shortening can be seen in Figure 9. In accordance with Figure 1 all the three mechanical parameters are more or less sensitive to the embedding of experimental specimens, mainly the failure load and the stiffness of KP vertebrae, but the least the deformability.

\section{Discussion}

All augmentation results highly depended on the embedding thickness. We can state that the thin embedding makes the specimens more sensitive than the thick one to the differences between the mechanical results of VP and KP vertebrae, as shown in Figures 1 and 8. Compared to the native vertebrae without embedding, the failure load was about $80 \%$ higher in the thick and only 10 $20 \%$ higher in thin embedded group. Since the thin embedding is closer to the anatomic situation, we can accept the values of thin embedded group as numerical results, however, the tendencies can be confirmed by the results of thick embedded group.

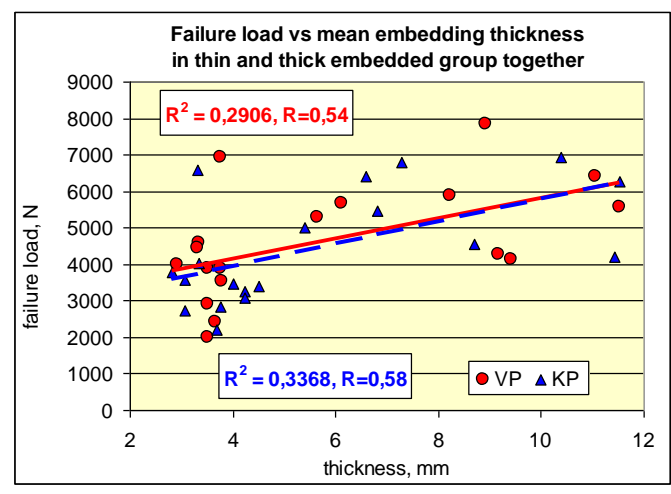

a)

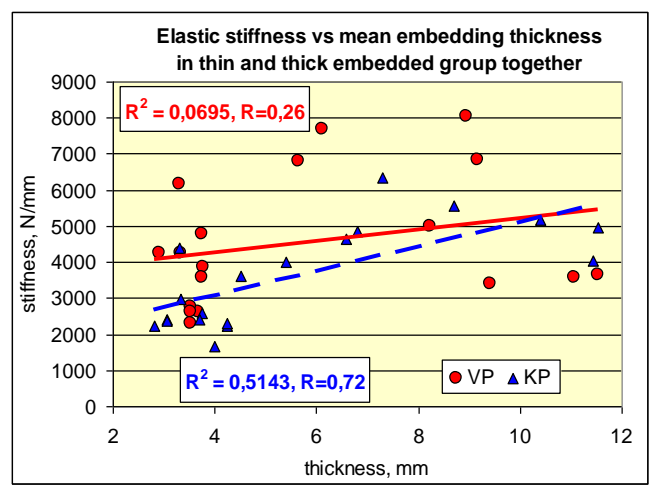

b)

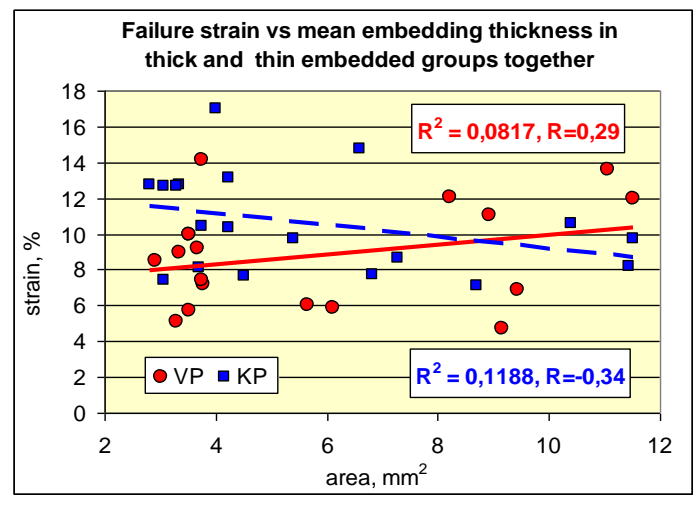

c)

Figure 9: Effect of embedding thickness on the a) failure load, b) elastic stiffness and c) failure strain of VP and KP vertebrae

Compressive failure loads of VP and KP vertebrae were practically equal within each embedding group. The similar values of ultimate loads of VP1 and KP1 vertebrae just like to VP2 and KP2 vertebrae in this study are in agreement with the conclusion of 21 that restoration of mechanical properties following PMMA cement augmentation was not significantly different for 
vertebroplasty and kyphoplasty. However, there were considerable differences in the stiffnesses within each embedding groups. The reason may be the less uniform or non-smooth load distribution and load transfer inside the vertebral body that increases the deformability and decreases the stiffness of vertebrae.

We conclude that due to VP and KP augmentation, the failure load and the stiffness equally increases. Failure load and stiffness are in a significant correlation with each other $(\mathrm{P}=0.012)$, mainly for the KP groups (0.0002), in particular in the thin embedded group ( $\mathrm{P}=0.002)$. The increase of the average failure load and stiffness of both VP and KP augmented vertebrae in this study were comparable with the results reported by ${ }^{9}$ where compared to the native control vertebrae, a statistically significant increase in vertebral stiffness and failure load was observed by VP augmentation with PMMA cement. The statistical analysis of compressive mechanical tests ${ }^{10}$ concluded that the failure load of vertebrae increased with prophylactic cement augmentation ${ }^{11}$ and with cement augmentation of fractures ${ }^{9,12-18}$. Stiffness after fracture augmentation has been reported to increase ${ }^{9,15,17}$ and to remain unchanged, ${ }^{14,18}$ but even to reduce. ${ }^{12-13}$

As for the deformability of augmented vertebrae, under repetitive loading conditions ${ }^{19}$ investigated the behavior of fractured osteoporotic vertebral bodies treated with either vertebroplasty or kyphoplasty. The authors concluded that vertebroplasty specimens had higher compression stiffness and smaller height reduction while kyphoplasty were initially taller, but because of a progressive loss of height during loading, the resulting constructs were shorter. Similar results were obtained in this study in the thin embedded group as the compressive strain loss of KP2 specimens was about 30\% higher than that of the VP2 group. Comparing the effect of vertebroplasty and kyphoplasty for motion segments ${ }^{20}$ concluded that the short-term mechanical effects of kyphoplasty were similar to those of vertebroplasty, with both procedures restoring stiffness, intradiscal pressure and spinal load sharing by a similar amount. Comparisons in $^{21}$ showed that the vertebral body heights were partially restored following both kyphoplasty and vertebroplasty, but most of this improvement was lost after creep loading. After the operation KP regained the height better than VP, but after the loading KP has more height loss.

Correlation of failure load and stiffness with the bone quality of thick and thin embedded VP and KP vertebrae shows uncertainty. The failure load of VP vertebrae showed a good positive correlation with CT grey values in thin and a weak negative correlation in thick embedding, while KP vertebrae had no correlation at all, neither in thick and nor in thin embedding. However, ${ }^{9}$ concluded that the stiffness and load bearing were inversely correlated to the bone mineral density (BMD) values in osteoporotic vertebral bodies, where the lower the initial BMD was, the more pronounced the augmentation effect was.

The positive correlation of failure load and partly of stiffness with the vertebral cross sectional areas is acceptable since a larger vertebra can contain more augmentation material consequently it can hold larger load.

The failure load in this study depends equally on the embedding both for VP and KP specimens, demonstrating that the vertebral load bearing increases with increasing embedding thickness both for VP and KP specimens, and so does mainly the stiffness of KP vertebrae as well since the deformability of KP specimens decreases with increasing embedding thickness.

The ratio of strength, stiffness and height loss of the vertebral body in the above references has been reported to depend upon the type and volume of cement, bone mineral density, sex or age 
of vertebrae, and experimental technique used. However, the influence of embedding type and thickness was not detailed in the mentioned studies; however, most of the experiments used embedded specimens that can determine the boundary conditions of the problem having a considerable influence on the experimentally obtained tissue properties, ${ }^{22-23,25}$ in particular on the trabecular tissue properties that can be extremely sensitive to the end-effects. The influence of boundary conditions on the experimental bone tissue characteristics is analyzed by microCT voxel-based large-scale finite element models in. ${ }^{24,26}$

\section{Conclusion}

In the present study two alternative vertebral augmentation techniques, vertebroplasty and balloon kyphoplasty were compared using axial compressive mechanical test. We can conclude that both techniques give practically the same failure load, vertebroplasty yields larger stiffness and smaller compressive deformability. Mechanical properties following VP are more sensitive to initial bone density than after KP. Embedding thickness affects the results considerably. The CT scans after the destructive tests will be analyzed in the near future.

\section{REFERENCES}

1. Karlsson MK, Hasserius R, Gerdhem P, Obrant KJ, Ohlin A. Vertebroplasty and kyphoplasty. New treatment strategies for fractures in the osteoporotic spine. Acta Orthopaedica, 2005;76(5):620-7.

2. Hulme PA, Krebs J, Ferguson SJ, Berlemann U. Vertebroplasty and Kyphoplasty: A Systematic Review of 69 Clinical Studies, Spine, 2006;31(17):1983-2001.

3. Taylor RS, Taylor RJ, Fritzell P. Balloon Kyphoplasty and Vertebroplasty for Vertebral Compression Fractures: A Comparative Systematic Review of Efficacy and Safety, Spine, 2006;31(23):2747-55.

4. Lavelle W, Carl A, Demers Lavelle E, Khaleel MA. Vertebroplasty and Kyphoplasty, Anesthesiology Clinics, 25, 2007. p. 913-28.

5. Taylor RS, Fritzell P, Taylor RJ. Balloon kyphoplasty in the management of vertebral compression fractures: an updated systematic review and meta-analysis, Eur Spine J., 2007;16:1085-1100.

6. McGirt MJ, Parker SL, Wolinsky JP, Witham TF, Bydon A, Gokaslan ZL. Vertebroplasty and kyphoplasty for the treatment of vertebral compression fractures: an evidenced-based review of the literature, The Spine Journal, 2009;9(6):501-8.

7. Han S, Wan S, Ning L, Tong Y, Zhang J, Fan S. Percutaneous vertebroplasty versus balloon kyphoplasty for treatment of osteoporotic vertebral compression fracture: a meta-analysis of randomised and non-randomised controlled trials, International Orthopaedics, 2011;35:1349-58.

8. Schmidt R, Cakir B, Mattes T, Wegener M, Puhl W, Richter M. Cement leakage during vertebroplasty: an underestimated problem? Eur. Spine J., 2005;14:466-73.

9. Heini PF, Berlemann U, Kaufmann M, Lippuner K, Fankhauser C, van Landuyt P. Augmentation of mechanical properties in osteoporotic vertebral bones - a biomechanical investigation of vertebroplasty efficacy with different bone cements. Eur Spine J. 2001;10(2):164-71.

10. Lieberman IH, Togawa D, Kayanja MM. Vertebroplasty and kyphoplasty: filler materials, The Spine Journal 2005;5:305-16.

11. Lim TH, Brebach GT, Renner SM, et al. Biomechanical evaluation of an injectable calcium phosphate cement for vertebroplasty. Spine, 2002;27:1297-302. 
12. Belkoff SM, Mathis JM, Erbe EM, et al. Biomechanical evaluation of a new bone cement for use in vertebroplasty. Spine, 2000;25:1061-4.

13. Belkoff SM, Mathis JM, Deramond H, et al. An ex vivo biomechanical evaluation of a hydroxyapatite cement for use with kyphoplasty. Am. J. Neuroradiol., 2001;22:1212-6.

14. Belkoff SM, Maroney M, Fenton DC, et al. An in vitro biomechanical evaluation of bone cements used in percutaneous vertebroplasty.Bone; 1999;25:23-6.

15. Belkoff SM, Mathis JM, Jasper LE, et al. The biomechanics of vertebroplasty: the effect of cement volume on mechanical behavior. Spine, 2001;26:1537-41.

16. Belkoff SM, Mathis JM, Jasper LE, et al. An ex vivo biomechanical evaluation of a hydroxyapatite cement for use with vertebroplasty. Spine, 2001;26:1542-6.

17. Molloy S, Mathis JM, Belkoff SM. The effect of vertebral body percentage fill on mechanical behavior during percutaneous vertebroplasty. Spine, 2003;28:1549-54.

18. Tohmeh AG, Mathis JM, Fenton DC, et al. Biomechanical efficacy of unipedicular versus bipedicular vertebroplasty for the management of osteoporotic compression fractures. Spine, 1999;24:1772-6.

19. Kim, M.J., Lindsey, D.P., Hannibal, M. Alamin, T.F., Vertebroplasty Versus Kyphoplasty: Biomechanical Behavior Under Repetitive Loading Conditions, Spine, 2006;31(18):2079-84.

20. Luo J, Adams MA, Dolan P. Vertebroplasty and Kyphoplasty Can Restore Normal Spine Mechanics following Osteoporotic Vertebral Fracture, Journal of Osteoporos, Published online, 2010 p. 9.

21. Luo J, Bertram W, Sangar D, Adams MA. Annesley-Williams, D.J., Dolan, P., Is kyphoplasty better than vertebroplasty in restoring normal mechanical function to an injured spine?, Bone, 2010;46,10507.

22. Odgaard A, Linde F. The underestimation of Young's modulus in compressive testing of cancellous bone specimens. Journal of Biomechanics, 1991;24:691-8.

23. Keaveny TM, Borchers RE, Gibson LJ, Hayes WC. Theoretical analysis of the experimental artifact in trabecular bone compressive modulus, Journal of Biomechanics, 1993;26:599-607.

24. Jacobs CR, Davis BR, Rieger, CJ, Francis JJ, Saad M, Fyhrie DP. The impact of boundary conditions and mesh size on the accuracy of cancellous bone tissue modulus determination using large-scale finite-element modeling, Journal of Biomechanics, 1999;32(11), 1159-64.

25. Un K., Bevill G, Keaveny TM. The effects of side-artifacts on the elastic modulus of trabecular bone. Journal of Biomechanics, 2006;39:1955-63.

26. Bevill G, Eswaran SK, Farahmand F, Keaveny TM. The influence of boundary conditions and loading mode on high-resolution finite element-computed trabecular tissue properties, Bone, 2009;44:573-8.

The authors gratefully acknowledge the Hungarian Scientific Research Fund OTKA for providing financial support in the frame of the grant $K$-075018. The authors are grateful to Lajos Borbás and Gábor Szebényi for their help in laboratory experiments. 